\title{
OPTICAL IMMUNE BIOSENSOR BASED ON SPR FOR THE DETECTION OF SALMONELLA TYPHIMURIUM
}

\author{
N. F. Starodub ${ }^{1,2}$, Ju. A. Ogorodnijchuk ${ }^{1}$, V. O. Romanov ${ }^{2}$ \\ ${ }^{1}$ National University of Life and Environmental Sciences, 15 Herojev Oboroni Str., Kiev, 03041 Ukraine; \\ ogorodniichuk@mail.ru \\ ${ }^{2}$ V.M. Glushkov Institute of Cybernetics of National Academy of Sciences of Ukraine
}

Summery. Salmonella typhimurium is one of the major pathogen dispersed through foodstuff. To avoid non-desirable effects on the health the control of foodstuff should be constant. The traditional approaches, which are used, as a rule, for the revealing of the infected organisms, are time consumable, routine and demand a special laboratory conditions with a very professional staff. For overcoming of these disadvantages there is necessary to develop instrumental methods, in particularly, based on the principles of biosensorics. The efficiency of the instrumental methods depends on many factors: technical characteristics of the registering part, specific preparation of biological sensitive layer and algorithm of fulfilled analysis. At the optimization of the general characteristics of the biosensor there is necessary to take into attention the main practice demands which concern sensitivity, specificity, rapidity, simplicity and low cost analysis. Unfortunately, in many cases, investigators involve or very expensive devices, or very complicate systems for the transducer preparation and analysis fulfilment.

We used the miniature SPR based device developed by Spreta (USA) as basis of the registering part and improved it by GPS system which can provide the immediately transferring of the obtained results in the stationary laboratory for the further verification of analysis and taking of the appropriate decision to restrict of the infection source. Analysis data are transferred from device to the medical centre or the laboratory by means of radio channel. As radio-transmitter it is used the original unit, which is developed by the company "VD MAIS". The procedure of the transducer preparation included several sequential steps: a) cleaning of surface by ethanol, b) covering of surface by polyalylamine hydrochloride c) immobilization of protein A from Staphylococcus aureus and, at last, the oriented binding of the specific antibodies. The model solution of $S$. typhimurium with the number of concentrations (from $10^{3}$ to $10^{8}$ cells $/ \mathrm{mL}$ ) was prepared in $0.9 \%$ of sodium chloride. The time of the sample incubation with the transducer surface was about 5 min and after that the last was washed by the above mentioned buffer. It was stated that the sensor sensitivity was on the level $10^{3}-10^{4}$ cells $/ \mathrm{mL}$ and linear field is situated from this level up to $10^{7}$ cells $/ \mathrm{mL}$. It is not sufficient sensitivity for all practice situations and, maybe, for its increasing there is necessary to find the most optimal variant of analysis from or/and to use the specific antibodies with high level of affinity.

Key words: Immune biosensor, SPR, salmonella, level, control.

\section{Introduction.}

The increasing incidence of food poisoning has become a significant public health concern for customers worldwide. Salmonella spp is one of the most frequently occurring food borne pathogens affecting the microbial safety of food and cause great concern in the food industry. Furthermore Salmonella infections are a serious medical and veterinary problem. Like other members of the bacterial family Enterobacteriaceae, species of Salmonella are gram-negative and rod-shaped. Salmonella do not require oxygen and their main habitat is the intestinal tract of animals. Salmonella species are motile and produce hydrogen sulfide. They generally do not ferment lactose.

Salmonella infections are zoonotic; they can be transmitted by humans to animals and vice versa. The microorganisms can be frequently found in sewage, sea, and river water and can contaminate a variety of food. Some Salmonella species are restricted to one or few animal species, whilst others have a wider host spectrum [1].

Salmonella nomenclature is complicated. Enterobacteriaceae family contains more then 2300 serovars, which are divided using somatic $\mathrm{O}$-antigen set at 46 serotipes. Using the structure of $\mathrm{H}$-antigen about 2500 serovars are known. But main mass of human disease and death are caused by relatively small group of serovars (10-12). Classification of Salmonella contains two species: S. enterica and S. bongori which are divided at 7 subspecies and marked with numbers or own names $-S$. enterica (I), salamae (II), arizonae (III), diarizonae (IIIb), houtenae (IV), indica (V) and bongori (VI). More often Salmonellosis is caused by representatives of I and II subspecies. Majority of Salmonella are pathogenic for human and for animals but in epidemiological meaning only a few of them have especially significant 
part. There are: S. typhimurium, S. enteritidis, S. panama, S. infantis, S. newport, S. agona, S. derby, S. london and some other agents that cause $85-91 \%$ cases of Salmonelosis [1]. The electron microscopy of S. typhimurium is given in Fig. 1
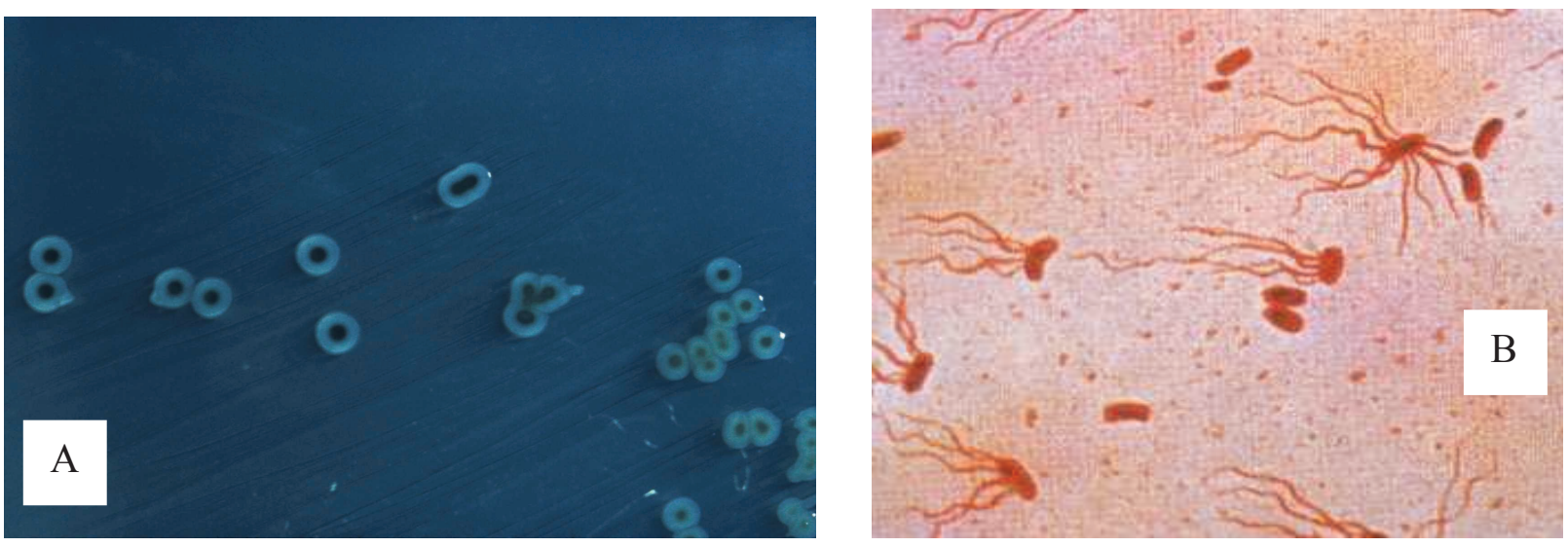

Fig. 1. A - Salmonella typhimurium at the electron microscopy; B - Flagellar stain of a S. typhimorium. Like E. coli, Salmonella are motile by means of peritrichous flagella.

Traditional methods [1, 2] for isolating and identifying Salmonella spp in foods relies on a multi-step process involving: preenrichment, selective enrichment in both selective and differential media, biochemical testing and serological confirmation. These cultural techniques for detection of Salmonella spp require $3-4$ days to provide presumptive results and an additional $1-2$ days for further biochemical confirmation [1]. As a rule the traditional approaches which are used for the revealing of the infected organisms are time consumable, routine and demand a special laboratory conditions with the very professional staff. For overcoming of these disadvantages there is necessary to develop instrumental methods, in particularly, based on the principles of biosensorics. Depending on the basic transducer principles, there are advances in biosensing technologies that use electrochemical, piezoelectric, optical, acoustic and thermal biosensors for detection of pathogenic bacteria [3-11].

The efficiency of the instrumental methods depends on all sides: technical characteristics of the registering part, specific preparation of biological sensitive layer and algorithm of analysis fulfillment. At the optimization of the general characteristics of the biosensor there is necessary to take into consideration the main practice demands which concern sensitivity, specificity, rapidity, simplicity and low cost analysis.

\section{Experimental.}

Among wide quantity of types of biosensors a special attention is paid that which based on the SPR with application of the different devices handmade in the laboratories and industrial produced: BIACORE (Sweden), Spreeta (USA) [3, 6, 12] as basis of the registering part. The laboratory-on-crystal Spreeta TSPR 1A170100 is manufactured by the company Nomadics, Inc on the base of SPR. Spreeta contains the prism with the sensitive surface. The prism has build-in the LED, the mirror, the photodetectors and the logic units. LED exit is connected by means of the optical line to the sensitive surface of the prism. The sensitive surface of the prism is connected by means of the optical line to the mirror, which has optical connection with the ruler of the photodetectors, exit of which is exit of the Spreeta. LED lights up sensitive surface and light beam beats off to mirror. Then reflected beam falls on the photodetectors of the Spreeta. Laboratory-on-crystal Spreeta converts the SPR curve shift to discrete pulses. These pulses are digitizing, processing in the portable device and then data are transferred by radio-channel.

Spreeta is device with three channels. It may directly connect to the computer for the registration of optical signal and its processing in advance. Moreover, this biosensor may have built in a simple computer unit and may be improved by GPS system which can provide the immediately transferring of the obtained results in the stationary laboratory for the further verification of analysis and taking of the appropriate decision to restrict of the infection source. The principal scheme of such device is presented in Fig. 2. Optical scheme of the Spreeta module is given in Fig. 3. To the sensitive module surface (which was presented gold layer) it was connected the special flow through cell and system for the control of the liquor injection with the help of the peristaltic pump as well as thermistor for temperature control and at the necessary for it stabilization. 
Obtained data and information about the place of the analysis are transferred from device to the medical center or the laboratory by means of radio channel through radio-transmitter developed by the company "VD MAIS" [13].

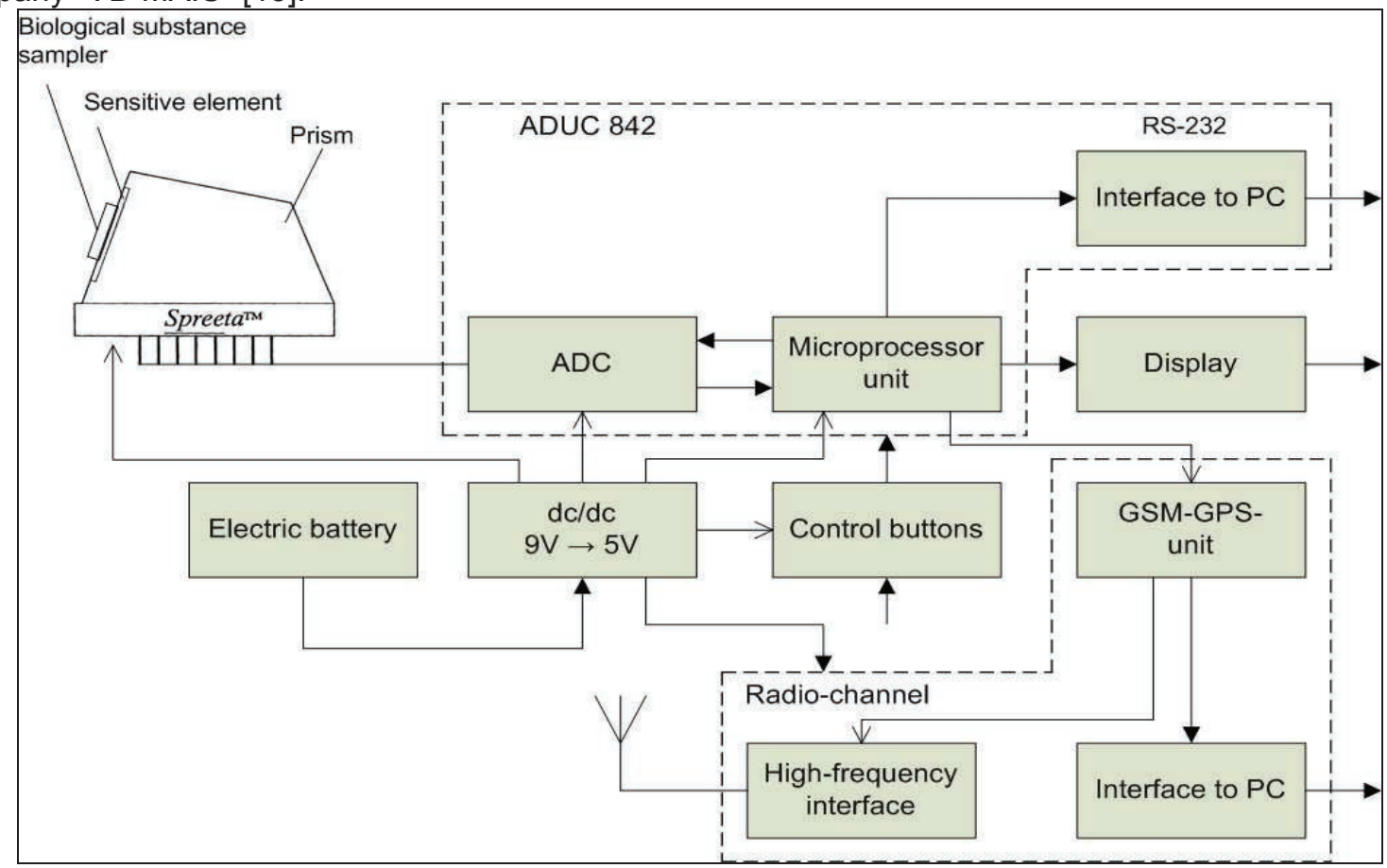

Fig. 2. Functional diagram of the device

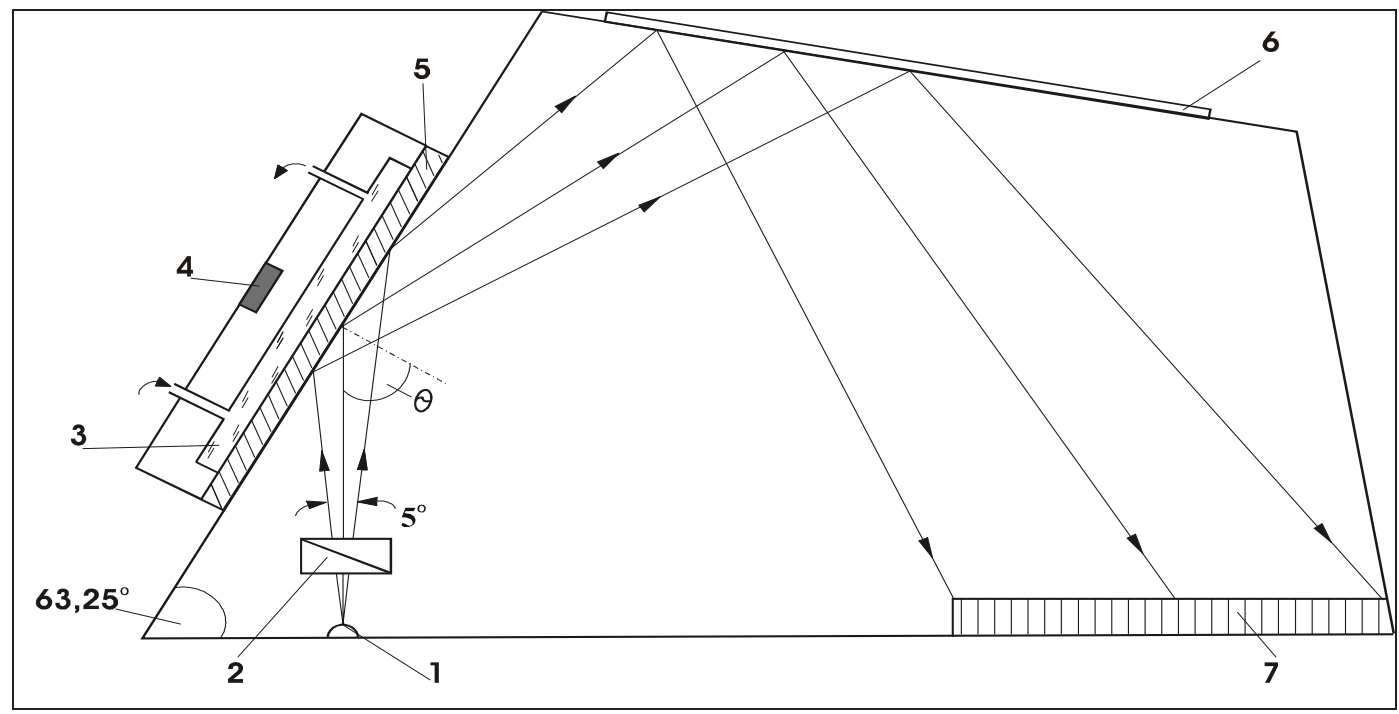

Fig. 3. Scheme of optical Spreeta module.

1 - light diode, 2 - polarizer, 3 - flow cell, 4 - thermistor, 5 - sensitive surface, 6 - mirror and 7 - line of 128 photo detectors with 128 -category movable register.

Principle of the operation is based on the transferring all data through the radio-channel (by means of the GSM-technology) directly to the Internet, and then to the server of the medical organization. On the first stage the SPR curve is measured when the device sensitive surface is covered only by layer from specific antibodies. The prism transforms optic signal of refraction angle into appropriate pulse sequence with different amplitude, which from prism exit comes in analog-digital converter (ADC). From ADC actual code values, which are proportional to SPR curve, enter to microprocessor unit. On the second stage the drop of investigated liquid is placed on the sensitive surface. If investigated liquid contains antigens, then, in concordance with "antibody-antigen" reaction, the refraction angle of prism optical signal will vary. New 
refraction angle is transformed by microprocessor unit into pulse sequence. Microprocessor unit detects the shift between these two SPR curves. In case of detecting of shift between these curves the microprocessor unit displays proper information on display and simultaneously transfers these data via GSM-communication to the server of necessary organization. The data about the place of measure, which are received by means of built-in GPS-system, are transferred together with information about presence of infection.

The procedure of the transducer preparation included several sequential steps: a) cleaning of surface by ethanol, b) covering of surface by polyalylamine hydrochloride c) immobilization of protein A from Staphylococcus aureus and, at last, the oriented binding of the specific antibodies. The sterilized and concentrated samples of $S$. typhimurium as well as the specific antibodies to this microorganism were prepared in the State Scientific-Research Control Institute of Veterinary Preparations and Feed Additives of Ukraine. The number of concentrations of S. typhimurium (from $10^{3}$ to $10^{8}$ cells $/ \mathrm{mL}$ ) were prepared in physiological solution $(0,9 \%$ of sodium chloride). The time of the sample incubation with the transducer surface was about 5 min and after that the last was washed by the above mentioned soltion.

\section{Results and discussion.}

An SPR biosensor is powerful tool for monitoring Salmonella infections. Among other biosensors Spreta showed fair sensitivity for the detection of Salmonella. It was stated that the sensor sensitivity was on the level $10^{3}$ cells $/ \mathrm{mL}$ and linear field is situated from this level up to $10^{7}$ cells $/ \mathrm{mL}$. But it is not sufficient sensitivity for all practice situations. Maybe, for its increasing there is necessary to find the most optimal variant of analysis or/an use the specific antibodies with high level of affinity. The diagram of the obtained results is presented in Fig. 4 (the changes of microorganism concentrations are indicated by the pointers from above and the start of washing - by ones from bellow).

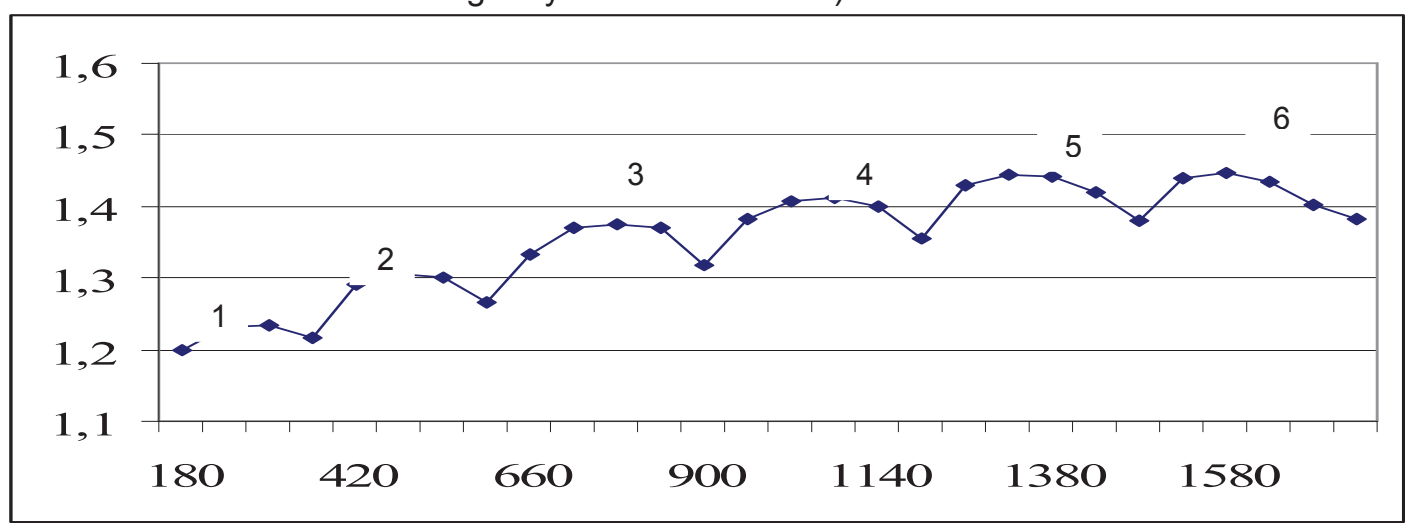

Fig. 4. Sensor diagram of the analysis of the different concentrations of

S. typhimurium. 1-6 - 10 $-10^{8}$ cells $/ \mathrm{mL}$. Abscissa - time (sec) and ordinate - change of resonant angle. The changes of microorganism concentrations are indicated by the pointers from above and the start of washing - by ones from bellow.

It is shown that signal of the immune biosensor has directly proportional dependence on the concentration of cells of S. typhimurium from $10^{3}$ to $10^{7}$ per $\mathrm{mL}$ (Fig. 5).

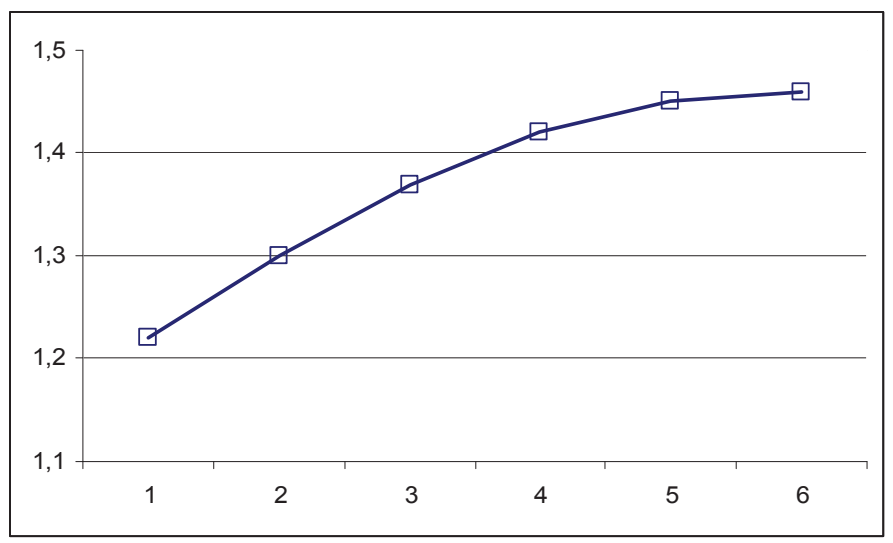

Fig. 5. Dependence of immune biosensor signal on concentration of cells of $S$. typhimurium in solution. Ordinate - change of resonant angle; Abscissa - 1-6 - $10^{3}-10^{8}$ cells $/ \mathrm{mL}$. 
In comparison with others [7] described an immunosensor based on SPR for the detection of S. typhimurium using protein $\mathrm{G}$ with a detection range of $10^{2}$ to $10^{9} \mathrm{CFU} / \mathrm{ml}$. Gertie et al. [ 8] used Biocore for the detection of Salmonella group. They have demonstrated that the minimal injected amount of cells to obtain a significant response corresponds with $1.7 \times 10^{3} \mathrm{CFU}$ per test portion (Table).

After all it is necessary to emphasize that recently an SPR method is widely used for the detection of pathogenic microorganisms [14-20]. As in ELISA, SPR detection is quick and cheap. But simultaneously along with high sensitivity another parameters for better work in real conditions must be developed. In our case we tried to provide the system for long-time monitoring of Salmonella used the miniature SPR based device as basis of the registering part and improved it by GPS system. It allows transferring obtained results immediately in the stationary laboratory for the further verification of analysis and taking of the appropriate decision to restrict of the infection source.

Table. Comparison of the characteristics of immune biosensors proposed for the determination of $S$. typhimurium concentration in model solution

\begin{tabular}{|c|c|c|c|}
\hline Item & Type of immune biosensor and its producer & Level of sensitivity & Linear diapason \\
\hline 1. & $\begin{array}{l}\text { Elaborated by us (SPR, intermediate layers - } \\
\text { polyelectrolites, protein A) }\end{array}$ & $10^{3}-10^{4}$ cells $/ \mathrm{mL}$ & $10^{3}-10^{\prime}$ cells $/ \mathrm{mL}$ \\
\hline 2. & $\begin{array}{l}\text { Elaborated by us (SPR, intermediate layers - } \\
\text { polyelectrolites, protein } \mathrm{G} \text { ) }\end{array}$ & $\begin{array}{l}2 \times 10^{2}-10^{3} \\
\text { cells } / \mathrm{mL}\end{array}$ & $\begin{array}{l}2 \times 10^{2}-10^{7} \\
\text { cells } / \mathrm{mL}\end{array}$ \\
\hline 3. & $\begin{array}{l}\text { Elaborated by us (SPR, intermediate layers - } \\
\text { dodecanthiol, protein A) }\end{array}$ & $\begin{array}{l}5 \times 10^{3}-10^{4} \\
\text { cells } / \mathrm{mL}\end{array}$ & $\begin{array}{l}5 \times 10^{3}-10^{\prime} \\
\text { cells } / \mathrm{mL}\end{array}$ \\
\hline 4. & $\begin{array}{l}\text { Oh Byung-Keum et al., } 2004 \text { (SPR, } \\
\text { intermediate layer - mercaptoundecanoic acid, } \\
\text { protein G ) }\end{array}$ & $10^{2}$ cells $/ \mathrm{mL}$ & $102-109$ cells $/ \mathrm{mL}$ \\
\hline 5. & Gertie et al., 2003 (Biacore, developed dextran) & $1.7 \times 10^{3} \mathrm{CFU} / \mathrm{mL}$ & - \\
\hline 6. & $\begin{array}{l}\text { Son et al., } 2007 \text { (SPR, intermediate layer - } \\
\text { neutravidin) }\end{array}$ & $10^{5} \mathrm{CFU} / \mathrm{mL}$ & - \\
\hline 7. & $\begin{array}{l}\text { Koubova et al., } 2001 \text { (SPR, direct physical } \\
\text { adsorption) }\end{array}$ & $10^{6}$ cells $/ \mathrm{mL}$ & - \\
\hline 8. & Lan Yu-bin at al., 2008 (SPR, & $1 \times 10^{6} \mathrm{CFU} / \mathrm{ml}$ & - \\
\hline
\end{tabular}

\section{Conclusion}

Diseases caused by food-borne pathogens constitute a world-wide increasing public health problem. Detection of bacterial contamination of food, therefore, is very important for public health protection $[6,7]$. Recently, SPR based immunosensors have been developed for the measurement of number of antigens with high specificity and sensitivity as well as with a short detection time and simplicity [5].

The portable SPR based device developed by Spreeta was used by us as a basis of the registering part for the detection of $S$. typhimurium. The sensor sensitivity was on the level $10^{3}-10^{7}$ cells $/ \mathrm{mL}$. But this sensitivity is not sufficient for all practice situations and subsequent work will be devoted to increase it. The improving of the developed immune biosensor by GPS system which is built in the radiotransmitter allows transferring obtained results immediately in the stationary laboratory for the further verification of analysis and taking of the appropriate decision to restrict of the infection source.

A special attention there is necessary to avoid procedures of sample preparations for analysis. They should include a number of steps: obtaining of quantitative extract from sample to be analyzed (in particular, if it is solid state substance) and providing pre-enrichment of the obtained extract bacteria, which are amenable to definition. The last step is very important since it can give possibility to achieve the desired sensitivity analysis for practice. This situation can be successfully resolved through pre-use express bioaffine column chromatography. The combination of immune biosensor analysis with preliminary application of such chromatography will be as the next task for authors.

\section{References}

1. Zarizkij A.M. Salmonellosis. K.: Zdorov'ja, 1988, 3, 160p.

2. Pividori M. Isabel, Merkoci Arben, Barbe Jordi, Alegret Salvador. PCR-Genosensor Rapid Test for Detecting Salmonella. J Electroanalysis, 2003, No.15, pp. 23-24

3. Betty G. M., Gortemaker J., Goverde R. L. J., Knapen F., Bergwerff A.A. Surface plasmon resonance (BIACORE) detection of serum antibodies against Salmonella enteritidis and Salmonella typhimurium. J. Immunol. Methods, 2002, v. 266, pp. 33-44.

4. Pathirama S.T., Barbaree J., Chin B.A., Hartell M.G., Neely W.C., Vodyanoy V. Rapid and sensitive biosensor for Salmonella. Biosens. Bioelectron., 2000, v. 15, pp.135-141. 
5. Wong Y.Y., Ng S.P., Ng N.H., Si S.H., Yao S.Z., Fung Y.S. Immunosensor for the differentiation and detection of Salmonella species based on a quartz crystal microbalance. Biosens. Bioelectron., 2002, v.17, pp. 676-684.

6. Spangler Brenda D., Wilkinson Elisabeth A., Murphy Jesse T., Tyler Bonnie J. Comparison of the Spreeta surface plasmon resonance sensor and a quartz crystal microbalance for detection of Escherichia coli heat-labile enterotoxin. Anal. Chim. Acta 2001, 444, pp. 149-161.

7. Oh, B.K., Kim, Y.K., K.W. Park, Lee, W.H., Choi, J.W. Surface plasmon resonance immunosensor for the detection of Salmonella typhimurium . Biosensors and Bioelectronics, 2004, v.19, pp. 1497-1504.

8. Gertie C.A., Bokken M., Corbee Ronald J., van Knapen Frans, Bergwerff Aldert A. Immunochemical detection of Salmonella group B, D and E using an optical surface plasmon resonance biosensor. J FEMS Microbiology Letters, 2003, v. 222, pp $75-82$.

9. Son J. R., Kim G., Kothapalli A., Morgan M.T., Ess D. Detection of Salmonella enteritidis using a miniature optical surface Plasmon resonance biosensor. J. Physics, 2007, v. 61, pp. 1086-1090.

10. Koubova V., Brynda E., Karasova L., Sïkvorc J., Homola J., Dostalek J., Tobisïka P., Rosïicky J. Detection of foodborne pathogens using surface plasmon resonance biosensors. Sensors and Actuators 2001, B 74, pp. 100105.

11. Lan Yu-bin, Wang Shi-zhou, Yin Yong-guang, Hoffmann W. Clint and Zheng Xian-zhe. Using a Surface Plasmon Resonance Biosensor for Rapid Detection of Salmonella Typhimurium in Chicken Carcass J. of Bionic Engineering 2008, v. 5, Issue 3, pp.239-246.

12. Chinowsky T.M., Quinn J.G., Bartholomew D.U.,Kaiser R., Elkind J.L. Performance of the Spreeta 2000 integrated surface plasmon resonance affinity sensor. Sensors and Actuators, 2003, B 91, pp. 266-274.

13. http://www.vdmais.kiev.ua.

14. Choi J. W., Lee W., Lee D. B., Park C. H., Kim J. S., Jang Y. H. and Kim Y. Electrochemical Detection of Pathogen Infection Using Cell Chip. Env. Monitoring and Assessment, 2007, v. 129, N. 1-3, pp. 37-42.

15. Starodub V.M., Starodub N.F. Electrochemical and optical biosensors: origin of development, achievements and perspectives of practical application.// In book of NATO series "Novel processes and control technologies in the food industry", Ed. Bozoglu F. at al., Amsterdam, 2001, pp. 63-94.

16. Starodub N. F., Rebriev A.V., Starodub V.M. Biosensors and express biochemical diagnostics of some diseases.// In book NATO series "Disease markers in exhaled breath", Ed. Marczin N. and Yacoub M., Amsterdam, 2002, pp. 391-394.

17. Starodub N.F., Pirogova L.V., Artyukh V.P., Starodub V.N. Biospecific interactions on the optical transducer surface the base of infection diagnostics.// In NATO book: "Frontiers of Multifunctional Nanosystems. Ed. Buzaneva E., Scharff P. Vol. 57, P. 369-376. 2002.

18. Romanov V., Starodub M., Galelyuka I., Skrypnyk O. Smart portable tester for express-diagnostics of bird flue: principles of design. In: Information Science and Computing. Int. Book series, "Intelligent Technologies and Applications", n 5. Suppl. to int. J. "Information Technologies and Knowledge" v 2, 2008, Ithea, Sofia, 2008, p. 80-84.

19. Starodub N.F. Biosensors in a system of instrumental tools to prevent effects of bioterrorism and automotive control of water process purification. In Proc.: NATO Science for Peace and Security, Ser. C: Environmental Security, Eds. J.A.A. Jones, T.G. Vardanian, Ch. Hakopian, Threats to Global Water Security, Springer Sci. + Business Media B.V., 2009, pp. 59-71.

20. Starodub N.F. Modern biooptical instruments for the express control of total toxicity, individual chemicals, viral and bacterial infections to prevent bio- and medical threats. In: NATO Science for Peace and Security Series E: Human and Social Dynamics, eds. A. Trufanov et.a., v. 62, "Pandemics and Bioterrotism", IOS Press, 2010, p. 127-133. 